\title{
Fenomena Pernikahan Usia Anak di Pesisir Selatan
}

\author{
Afrina Yanti, Fatmariza \\ Program Studi Pendidikan Pancasila dan Kewarganegaraan \\ Universitas Negeri Padang \\ E-mail: afrinayanti9@gmail.com
}

\section{ABSTRAK}

Pernikahan anak merupakan salah satu bentuk pelanggaran konstitusi. Namun pada budaya tertentu Pernikahan anak dianggap sebagai suatu kelaziman. Artikel ini bertujuan untuk mengelaborasi bagaimana fenomena pernikahan anak dalam tepatnya di kampung Akad Kenagarian Padang XI Punggasan Kab. Pesisir Selatan. Untuk itu penelitian ini menggunakan metode kualitatif dengan pendekatan deskriptif, data didapat dari sumber data primer dan data sekunder dengan teknik observasi, wawancara, dan dokumentasi, serta wawancara mendalam dengan informan penelitian. Informan penelitian terdiri dari kepala KUA, wali nagari, wali kampung, petua adat, tokoh agama, guru, pasangan yang menikah pada usia anak, orang tua pasangan yang menikah pada usia anak, dan masyarakat dikampung Akad. Hasil penelitian ini menunjukkan bahwa Pernikahan anak dipengaruhi oleh faktor pendidikan orang tua, faktor kemiskinan/ekonomi, faktor tradisi/ sosial budaya, dan faktor pergaulan bebas.Sedangkan dampak dari Pernikahan anak dalam perspektif sosial budaya ini dapat dilihat dari segi keluarga, segi ekonomi, dan segi lingkungan sosial.Pernikahan anak dikampung Akad kenagarian Padang XI Punggasan terus terjadi dan belum bisa dihilangkan, walaupun sudah ada sosialisasi dari lembaga pemerintah. Kesimpulan pernikahan anak dikampung Akad menunjukan bahwa pernikahan anak masih banyak terjadi, hal ini juga dipengaruhi oleh faktor-faktor yang mendukung terjadinya pernikahan anak dikampung Akad. Dari hasil penelitian ini dapat disimpulkan bahwa faktor pendidikan orang tua dan tradisi/budaya menjadi faktor utama terjadinya pernikahan anak di kampung Akad. Sedangkan dampak dari pernikahan anak dikampung Akad rata-rata sudah bercerai dan tidak harmonis.

Kata Kunci: Fenomena, Pernikahan, Anak

\section{ABSTRACT}

Child marriage is a violation of the constitution. But in certain cultures, child marriage is considered as a norm. This article aims to elaborate on how the phenomenon of child marriage is precisely in Kampung Akad Kenagarian Padang XI Punggasan. Pesisir Selatan. For this reason, this study used qualitative method with descriptive approach, the data was obtained from primary data sources and secondary data with observation, interviews, and documentation techniques, as well as in-depth interviews with research informants. The research informants consisted of the leader of the KUA, the guardian of the nagari, the guardian of the village, cultural leaders, religious leaders, teachers, couples who 
were married at the age of the child, parents who were married at the age of the children, and the community in Kampung Akad. The results of this study indicated that child marriage was influenced by parental education factors, poverty / economic factors, cultural / social cultural factors, and promiscuity factors. While the impact of child marriage in this socio-cultural perspective could be seen in terms of family, economic, and social environment aspects. Child marriage in Kampung Akd Padang XI Punggasan continued to occur and could not be eliminated, although there had been socialization from government agencies. Conclusion of child marriage in Kampung Akad showed that child marriage was still a lot happening, this was also influenced by factors that support the occurrence of child marriage in Kampung Akad. From the results of this study it can be concluded that the factors of parental education and tradition / culture are the main factors of child marriage in Kampung Akad. While the impact of child marriages in Kampung Akad is on average divorced and out of harmony.

Keywords : Phenomenon, Marriage, Children

This work is licensed under the Creative Commons Attribution-ShareAlike 4.0 International License. (O2019 by author and Universitas Negeri Padang.

Received: 2019-07-12 Accepted: 2019-09-02

\section{PENDAHULUAN}

Pernikahan anak yang selama ini terjadi tidak sesuai dengan anjuran yang telah ditetapkan oleh UU di Indonesia ini. Hal ini membuat peneliti tertarik untuk melakukan penelitian tentang pernikahan anak di kampung Akad.Terlihat bahwa dibeberapa daerah maupun kota masih saja ada yang melakukan pernikahan anak, tidak terkecuali di kampung Akad padang XI punggasan kabupaten pesisir selatan. Dari permasalahan yang dapat diangkat, faktor penyebab dan dampak pernikahan anak menarik untuk diteliti. Pernikahan anak ini sudah menjadi hal yang membudaya dibeberapa daerah termasuk kampung akad padang XI punggasan pesisir selatan. Pernikahan anak di Kampung Akad merupakan hal yang sudah biasa terjadi, bahkan kebanyakan dari orang tua mereka menginginkan putra putri mereka untuk segera menikah diusia yang masih muda. Persepsi masyarakat tentang biaya pendidikan yang mahal menjadi ketakutan bagi orang tua untuk mengeluarkan biaya pendidikan bagi sang anak. Seringkali mereka menyarankan anak-anak mereka untuk putus sekolah dan segera menikah diusia yang masih belia.

Penelitian ini didukung oleh beberapa jurnal yang berkaitan dengan tema pernikahan anak.dari beberapa jurnal yang berkaitan, jurnal candraningrum tentang pernikahan anak: status anak perempuan dan Wulandari (2014) menjelaskan pengaruh status ekonomi keluarga terhadap motif menikah dini dipedesaan, penyebab pernikahan anak pada umumnya disebabkan oleh faktor pendidikan yang masih rendah dan kemiskin. Kemudian jurnal yang membahas tentang pernikahan anak lainya yaitu jurnal (Aprianti, 2018). Pilihan yang diambil orang tua dalam menghadapi kehamilan tidak diinginkan (KTD) paling banyak adalah menikahkan remaja, karena dengan menikahkan remaja yang yang KDT dapat menutupi rasa malu 
keluarga dan dianggap cara yang paling efektif menyelesaikan permasalahan KDT.

Meskipun usia remaja yang masih dini untuk menikah tidak menjadi permasalahan bagi keluarga, karena budaya masyarakat Indonesia yang menerima pernikahan usia dini. Kemudian jurnal (Artono. 2016). Mengatakan salah satu fungsi utama keluarga adalah memberikan perhatian dan kasih sayang (afeksi) terhadap keluarganya. Selain itu keluarga adalah wahana untuk melakukan sosialisai, pendidikan norma sosial, dan etika kehidupan bagi generasi penerus. Perbedaan penelitian ini dengan penelitian sebelumnya yang telah dibahas oleh beberapa jurnal diatas, terletak pada kajian yang dibahas, yaitu penelitian ini melihat fenomena pernikahan anak.Penulisan artikel ini merujuk pada beberapa jurnal yang membahas mengenai pernikahan anak.

Dari penelitian yang saya lakukan, terdapat sebuah upaya yang dapat dilakukan oleh pemerintah terhadap maraknya pernikahan pada usia anak di kampung Akad yaitu dengan memberikan penyuluhan tentang dampak dari pernikahan anak. Karena dengan adanya penyuluhan dari pemerintah tentunya akan menambah pengetahuan masyarakat akan dampak dari pernikahan anak. Dari hasil temuan peneliti dilapangan faktor pendidikan orang tua dan tradisi/budaya menikah pada usia anak merupakan salah satu faktor utama penyebab terjadinya pernikahan anak di kampung Akad, dan belum ada upaya dari pemerintah untuk memberantas terjadinya pernikahana anak di kampung Akad seperti penyuluhan yang seharusnya dilakukan oleh pemerintah setempat.

Berdasarkan observasi dan wawancara peneliti dilapangan dapat disimpulkan bahwa dari tahun 2014 sampai 2018, ada 28 pasangan yang telah melakukan pernikahan anak. Dari 28 pasangan yang menikah, perempuan yang menikah muda mulai dari umur 13 tahun sampai 16 tahun, dan laki-laki mulai dari umur 15 tahun sampai 18 tahun.Pasangan yang tidak harmonis ada 10 , pasangan yang cerai 10 , pasangan yang menikah lagi 5 , dan pasangan yang harmonis 3 . Selain pasangan yang menikah di usia anak, ada juga pasangan yang menikah dengan perbedaan usia yang cukup jauh. Seperti perempuan berumur 14 tahun, sedangkan laki-laki berumur 30 tahun.Tujuan dari penulisan artikel ini adalah untuk memperlihatkan bahwa faktor penyebab dari pernikahan anak disebabkan oleh kurangnya pendidikan orang tua dan faktor sosial budaya sehingga mendorong terjadinya pernikahan pada usia anak, dan dapat mengetahui apa saja dampak dari pernikahan di kampung Akad.

\section{Pernikahan usia anak dalam perspektif budaya}

Menurut hasil penelitian yang dilakukan BKKBN pada tahun 2014, 46 persen atau setara 2,5 juta pernikahan yang terjadi disetiap tahun di Indonesia mempelai perempuannya berusia antara 15 sampai 19 tahun. Bahkan 5 persen diantarannya melibatkan mempelai perempuan yang berusia di bawah 15 tahun. Dalam suatu lingkungan, masyarakat harus menjalin suatu komunikasi yang baik antar sesama, karna dengan komunikasi yang berjalan dengan lancar akan mempermudah menjalin 
hubungan yang baik dalam suatu lingkungan masyarakat (Salmah, 2017). Termasuk masalah terjadinnya pernikahan anak disuatu lingkungan masyarakat. Masyarakat harus saling bekerjasama, untuk mencegah terjadinnya pernikahan anak, karena pernikahan anak ini sangat beresiko, baik bagi pasangan yang menikah tersebut maupun bagi lingkungan sekitar.

Pernikahan anak sering terjadi karna berbagai alasan, ada yang terjadi disebabkan oleh faktor internal dan ada juga yang disebabkan oleh faktor eksternal. Faktor eksternal adalah faktor dari luar seperti dorongan dari orang tua dan media sosial yang menyebabkan para remaja terlibat dalam kenakalan remaja yang akhirnya mengharuskan mereka untuk melakukan pernikahan di usia yang masih belia. Sedangkan faktor internal adalah faktor dari dalam diri untuk melakukan pernikahan usia muda seperti adanya dorongan dari diri sendiri untuk menjalani sebuah rumah tangga.Pernikahan anak juga tidak terlepas dari faktor pendidikan dan lingkungan, semakin tinggi pendidikan seseorang maka akan semakin lama juga ia akan menikah. Lingkungan juga memberikan pengaruh yang besar dalam terjadinnya pernikahan anak, kenakalan remaja dan pergaulan bebas menyebabkan hamil luar nikah yang akan mendorong pernikahan anak. Berdasarkan paparan diatas, maka perkawinan anak yang dimaksud dalam penelitian ini adalah perkawinan yang dilakukan oleh lakilaki atau perempuan yang berusia delapan belas (18) tahun kebawah.
Faktor penyebab pernikahan usia anak

\section{a. Faktor pendidikan}

Pendidikan adalah usaha yang sengaja dan terencana untuk membantu perkembangan potensi dan kemampuan anak agar bermanfaat bagi kepentingan hidupnya sebagai warga negara/masyarakat, dengan memilih isi (materi), strategi kegiatan dan teknik penilaian yang sesuai (Suryosubroto, 2010). Kurangnnya kesempatan melanjutkan pendidikan menjadi salah satu faktor penyebab terjadinnya pernikahan anak.Anakanak yang seharusnya berada pada bangku pendidikan, tetapi pada kenyataannya mereka tidak mempunyai kesempatan untuk memperoleh pendidikan, ini diakibatkan oleh kebanyakan anakanak hanya tamatan SLTP, lalu putus sekolah.pasangan yang menikah di usia anak tidak memiliki banyak pengetahuan bagaimana membina suatu rumah tangga yang baik. Karena terhentinya pendidikan, maka anakanak akan menjadi pengangguran sehingga lama-kelamaan mereka akan menikah di usia yang masih muda.

\section{b. Faktor kemiskinan/ekonomi}

Kemiskinan merupakan sebuah kondisi yang berada dibawah garis nilai standar kebutuhan minimum, baik untuk makanan maupun non makanan, yang disebut garis kemiskinan (poverty line) atau batas kemiskinan (poverty threshold) Sjafari (2014). Kemiskinan akan menimbulkan masalah ekonomi, sedangkan untuk membentuk sebuah rumah tangga harus memperhatikan sosial ekonominnya. Menurut Walgito (2002), seseorang yang telah berani membentuk keluarga melalui pernikahan, segala tanggungjawab 
dalam hal menghadapi keluarga itu terletak pada pasangan tersebut bukan pada orang lain, termasuk orng tua.

Keadaan ekonomi keluarga yang rendah mendorong remaja untuk berkeinginan bekerja diluar negeri. Keinginan tersebut berkaitan dengan keinginan segera menikah. Sejalan dengan norma yang berkembang dilapangan bahwa terdapat nilai yang berkembang bahwa anak perempuan merupakan aset ekonomi keluarga, yang mana anak perempuan diharapkan dapat meningkatkan derajat ekonomi keluarga. Jadi, dapat dipahami bahwa faktor kemiskinan dapat mendorong terjadinnya pernikahan usia anak disebabkan oleh kesulitan keuangan dan kesulitan ekonomi.

\section{c. Tradisi/budaya}

Budaya berasal dari kata sanskerta "buddhi", bentuk jamaknya "buddhayah" yang berarti "budi" atau "akal", yaitu hal-hal yang bersangkutan dengan budi atau akal manusia. Faktor budaya merupakan pemicu terjadinnya pernikahan anak di beberapa daerah (Sobarsa, 2015). Budaya disuatu daerah mempengaruhi masyarakat sekitar untuk kawasan tersebut untuk melansungkan pernikahan anak karena telah terjadi secara turuntemurun.

\section{Dampak pernikahan usia anak}

Pernikahan merupakan hal yang tidak mudah untuk dijalani oleh setiap pasangan suami istri.Karena selain tanggungjawab, pernikahan juga memerlukan kesiapan mental untuk membina sebuah rumah tangga.Pasangan yang menikah muda cendrung membutuhkan dukungan dan bantuan dari orang tua.karena mereka belum sepenuhnya mandiri dalam pengasuhan anak.Selain itu, rata-rata pasangan yang menikah muda belum memiliki ekonomi yang mapan.

Seringkali pernikahan dibawah umur terjadi karena pergaulan bebas sehingga terjadi kehamilan diluar nikah.Peraulan bebas juga terjadi karena orangtua tidak sanggup membiayai pendidikan sehingga menuntut anak untuk putus sekolah dan akhirnya terlibat pada pergaulan bebas. Hal ini juga diperparah lagi dengan kurangnya kontrol dari orangtua.Pasangan suami istri yang menikah muda sering mengalami masalah sosial ekonomi, masa depan keluarga yang suram akibat putus sekolah, rentan terjadi perceraian dan kekerasan dalam rumah tangga (KDRT).

$$
\text { Kesiapan spikologis juga penting }
$$
dalam memasuki kehidupan pernikahan agar masing-masing individu siap dalam menghadapi berbagai masalah dengan bijak dan teliti. Ketidaksiapan individu dalam membina rumah tangga akan menimbulkan masalah-masalah dalam keluarga yang akan berujuang pada perceraian. Kartasapoetra (1987) menjelaskan perceraian adalah pengakhiran ikatan pernikahan. Perceraian sedikit banyaknya akan mempengaruhi lingkungan masyarakat. Individu yang menikah di usia anak cendrung akan bergantung pada keluarga karena belum memiliki kesiapan. Ketidaksiapan dalam bidang ekonomi akan menjadi rintangan bagi pasangan yang menikah diusia muda, karena setiap keluarga pasti akan memerlukan biaya untuk melansungkan kehidupan sehari-hari. Menikah di usia yang masih muda akan berakibat pada masa depan anak- 
anak, apalagi jika kondisi ekonomi juga tidak berjalan dengan lancar. Hal ini tentu saja akan menimbulkan masalah dalam keluarga, seperti pertengkaran, kekerasan dalam rumah tangga.

\section{METODE PENELITIAN}

Jenis penelitian yang digunakan dalam penelitian ini adalah penelitian kualitatif dengan pendekatan deskriftif. Menurut Maleong (2005) penelitian kualitatif adalah penelitian yang memanfaatkan wawancara terbuka untuk menelaah dan memahami sikap, pandangan, perasaan dan prilaku individu atau sekelompok orang. Penelitian ini dilansanakan di kampung Akad Kenagarian Padang XI Punggasan Kabupaten Pesisir Selatan yang menjadi salah satu desa yang melakukan pernikahan anak dalam Perspektif Sosial Budaya. Informan penelitian dilakukan dengan purposive sampling yang berjumlah 10 orang informan yang melakukan pernikahan anak, orang tua pasangan yang menikah anak, wali kampung, wali nagari, kepala KUA, serta masyarakat yang tinggal di kampung Akad Kenagarian Padang XI Punggasan Kabupaten Pesisir Selatan. Jenis data yang digunakan dalam penelitian ini adalah data primer dan data sekunder.Teknik pengumpulan data dilakukan dengan observasi, wawancara, dan dokumentasi.Alat pengumpulan data yang digunakan dalam penelitian ini adalah pedoman wawancara terhadap informan serta penggunaan handphone sebagai alat perekam, disamping itu peneliti juga menggunakan kamera untuk keperluan dokumentasi serta observasi lapangan.Uji keabsahan data dengan teknik trianguasi data. Teknis analisis data yang digunakan dalam penelitian ini terdiri dari lima komponen yaitu, pengumpulan data, reduksi data, penyajian data, verivikasi data, dan penarikan kesimpulan.

\section{HASIL DAN PEMBAHASAN}

Faktor-faktor penyebab pernikahan usia anak dalam di kampung Akad kenagarian padang XI Punggasan Pesisir Selatan

\section{a. Faktor Pendidikan orang tua}

Pernikahan usia anak di kampung Akad kenagarian padang XI Punggasan disebabkan oleh faktor kurangnya pendidikan masyarakat. pendidikan merupakan salah satu faktor yang mempengaruhi persepsi seseorang, karena dengan pendidikan yang tinggu akan seseorang akan lebih mudah menerima atau memilih suatu perubahan yang lebih baik, karena pendidikan akan menambah wawasan seseorang. Menurut Reskia (2014), orang tua bertanggungjawab atas pendidikan anak-anaknya untuk menerima tanggungjawab yang penting ini, maka harus mempersiapkan diri sebelum dan sesudah menikah. Namun sebagian masyarakat menikah tanpa persiapan diri yang matang dan beranggapan bahwa pendidikan tidaklah penting dan pendidikan tidak akan menjamin masa depan seseorang akan lebih baik.

Tingkat pendidikan yang tinggi menggambarkan kematangan pribadi seseorang dalam bertindak. Sehingga masyarakat yang berpendidikan tidak akan mau menikah di usia anak, agar terhindar dari dampak-dampak pernikahan anak yang akan merugikan dirinya sendiri. Namun yang terjadi di kampung akad, 
beberapa masyarakat beranggapan bahwa pendidikan tidaklah penting dan pendidikan tidak akan menjamin masa depan seseorang akan lebih baik.

\section{b. Faktor kemiskinan/ekonomi}

Pernikahan usia anak di kampung Akad kenagarian padang XI Punggasan disebabkan oleh faktor kemiskinan/ekonomi. Ketika kekurangan ekonomi dalam keluarga (perempuan) menjadi permasalahan, anak gadis sering dikatakan sebagai beban bagi keluarga dan memberatkan orang tua. Oleh karena itu jika ada yang bertanya (meminang) maka orang tua lansung setuju walaupun jika perbedaan usia sangat berbeda jauh. Bahkan ada orang tua yang menyuruh anaknya untuk berhenti sekolah supaya nanti kalau sudah tidak sekolah laki-laki tidak akan segan untuk meminang mereka. Selain itu, sanak saudara mereka juga mendukung anak-anak untuk menikah cepat, salah satunya dengan cara mencarikan calon suami yang mau menikah dengan anak-anak mereka supaya nanti suami anaknya bisa membantu perekonomian keluarganya. Menutut Djamilah (2014) umumnya faktor ekonomi terjadi karena perjodohan ataupun putus sekolah karena tidak memiliki biaya untuk pendidikan. Masyarakat beranggapan bahwa dengan melakukan pernikahan anak dapat meringankan beban keluarga dengan adanya suami anaknya yang bisa memberi nafkah mereka. Orang tua seringkali tidak memikirkan dampak pernikahan anak yang akan merusak anaknya karna belum adanya kesiapan fisik maupun mentalnya.
Kondisi Rumah Dan Kondisi Anak Dari Pasangan Yang

PernikahanUsiaAnak Di Kampung Akad

Gambar 1. Kondisi Rumah Dan Kondisi Anak Dari Pasangan Yang PernikahanUsiaAnak Di Kampung Akad

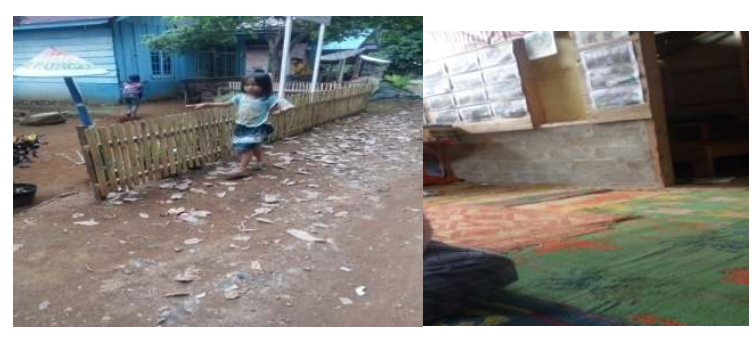

(Sumber: Dokumentasi Pribadi Peneliti 11 Juni 2019)

c. Aktor tradisi/sosial budaya

Tradisi/budaya adalah suatu kebiasaan dalam suatu masyarakat. Budaya disuatu daerah mempengaruhi masyarakat untuk melansungkan pernikahan anak, termasuk kampung Akad. Sosial budaya adalah segala aspek kehidupan yang merupakan gabungan dari tata nilai, tata sosial, dan tata laku manusia yang merupakan karya dalam kehidupan bermasyarakat yang mencangkup dua segi kehidupan manusia yaitu segi kemasyarakatan dan kebudayaan (Sudibyo, 2013). Masyarakat kampung akad banyak melakukan pernikahan anak dikarnakan faktor budaya ini.Rata-rata masyarakat kampung akad melakukan pernikahan anak karena masyarakat menganggap pernikahan anak adalah sesuatu yang lumbrah terjadi, dan bukan merupakan sebuah aib kalau melakukan pernikahan anak. Masyarakat seringkali tidak enggan menyuruh anaknya untuk menikah secepat mungkin dan bahkan ada yang menyuruh anak mereka berhenti sekolah supaya ada laki-laki yang meminangnya. Namun selain karena didorong oleh orang tua, banyak juga anak yang menikah dengan 
keinginannya sendiri karena melihat teman sebayanya sudah menikah.

Gambar 2 tradisi/budaya yang mendukung terjadinya pernikahan usiaanak di kampung Akad

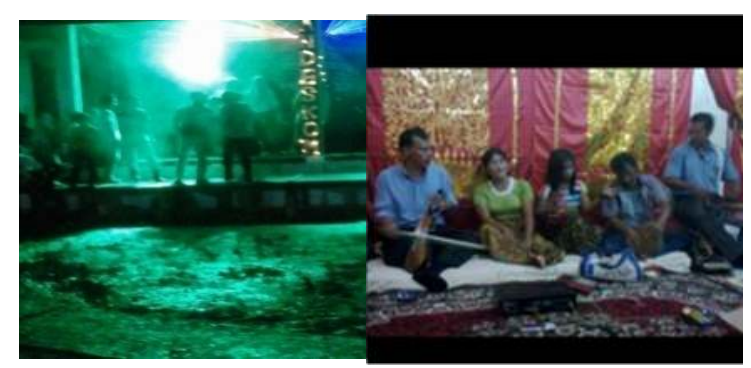

(Sumber: Masyarakat 3 April 2019)

\section{d. Pergaulan Bebas}

Pergaulan bebas sangat erat kaitanya dengan seks bebas dan hamil di luar nikah. Pergaulan bebas sering terjadi di kalangan para remaja, tanpa pengawasan dan perhatian orang tua terhadap anak akan menjerumuskan anak dalam pergaulan bebas. Banyaknya pernikahan anak dikampung Akad dikarenakan sudah hamil diluar nikah akibat pergaulan bebas. Hal ini sejalan dengan pendapat (Suhaida, 2018) pergaulan bebas di kalangan pelajar disebabkan oleh pergeseran budaya, kurangnya perhatian orang tua, teman dekat, dan media dari berbagai faktor tersebut berdampak pada menurunnya prestasi pelajar, putus sekolah dan hamil di luar nikah. Berdasarkan pendapat diatas dapat disimpulkan bahwa Kurangnya pengawasan orang tua terhadap anak karena orang tua sibuk bekerja berangkat pagi dan pulang sore. Hal ini membuat anak-anak dikampung akad sering melakukan pergaulan bebas hingga hamil di luar nikah. Sebelumnya hamil diluar nikah adalah aib bagi keluarga, namun karena sudah sering terjadi di kalangan masyarakat kampung akad,
Volume 2 No. 42019

lama-kelamaan menjadi hal yang sudah biasa terjadi.

Dampak pernikahan usiaanak di kampung Akad kenagarian padang XI Punggasan Pesisir Selatan.

\section{a. Aspek Keluarga}

Keluarga adalah kelompok sosial yang bersifat pribadi, keluarga merupakan tempat yang paling penting dimana anak memperoleh dasar dalam membentuk kemampuannya (Siregar, 2013). Menikah bukanlah perkara mudah yang bisa dilalui tanpa Persiapan yang matang dari pasangan suami istri.Banyak diantara pasangan yang menikah mengalami kegagalan dalam rumah tangganya, tidak terkecuali pasangan yang melakukan pernikahan anak.Masyarakat yang melakukan pernikahan anak seringkali belum mempersiapkan dirinya untuk menghadapipernikahan.

Permasalahan dalam keluarga sesudah menikah seringkali muncul karena kurangnya persiapan dari kedua belah pihak. Perceraian seringkali menjadi akhir suatu pernikahan yang dilakukan oleh anak. Hal ini juga terjadi pada masyarakat kampung Akad. Masyarakat kampung akad seringkali melakukan pernikahan tanpa persiapan yang matang, sehingga berdakpak pada keluarganya. Masyarakat kampung akad banyak mengalami kegagalan dalam rumah tangga.Permasalahan dalam keluarga sering terjadi karena belum bisa mengontrol emosi dan kesiapan mental dalam menghadapi masalah keluarga.

\section{b. Aspek Ekonomi}

Menurut Sjafari

Kemiskinan merupakan sebuah kondisi yang berada dibawah garis 
nilai standard kebutuhan minimum, baik untuk makanan maupun non makanan, yang disebut garis kemiskinan (poverty line) atau batas kemiskinan (poverty threshold). Untuk melakukan pernikahan dibutuhkan kemapanan dalam segi ekonomi, mengingat bahwa biaya hidup setelah menikah sangat jauh berbeda dengan biaya hidup sebelum menikah. Sebelum menikah kita perlu mempersiapkan diri dengan melihat apakah keuangan kita sudah bisa untuk menanggung biaya hidup dalam rumah tangga.Pasangan yang melakukan pernikahan anak seringkali tidak mempedulikan persiapan dari segi ekonomi.Kesiapan dari segi ekonomi perlu dipersiapkan agar terhindar dari masalah setelah menikah.Banyak diantara pasangan yang melakukan pernikahan anak hanya mengambil status saja, tanpa adanya persipan yang matang dari segi ekonomi.Dampak pernikahan anak yang dilakukan oleh masyarakat kampung akad dari segi ekonomi sering terlihat bahwa banyak pasangan yang setelah menikah masih membenani orang tuanya.Rata-rata pasanagan yang melakukan pernikahan anak di kampung akad masih tinggal bersama orang tuanya.Bahkan pasangan yang sudah bercerai beserta anaknya dibiayai kembali oleh orangtuanya karna sudah tidak dibiayai lagi oleh orang tuanya.

\section{c. Aspek Lingkungan Sosial}

Lingkungan sosial merupakan salah satu cara masyarakat melakukan perubahan. Lingkungan sosial berkaitan dengan hubungan bermasyarakat. Lingkungan sosial yang baik akan membawa perubahan prilaku yang baik pula kepada kita, tetapi jika lingkungan sosial yang tidak baik akan member kehancuran bagi kita. Namun ada beberapa orang tidak mampu menjalin hubungan yang baik dengan lingkunganya dikarenakan berbagai macam hal. Hal seperti inilah yang akan membuat kita merasa tidak nyaman untuk tinggal disuatu wilayah. Masyarakat yang melakukan pernikahan anak banyak yang tidak mampu menjalin hubungan yang baik dengan lingkungan sosialnya karena berbagai macam penyebab. Seperti masyarakat yang menikah karna pergaulan bebas yang mengharuskan mereka menikah karena hamil di luar nikah. Menurut (Djamilah, 2014) pernikahan anak karena hamil di luar nikah menyebabkan mereka kurang diterima oleh keluarga sendiri maupun lingkungan sosialnya. Mereka seringkali dikucilkan dan menjadi bahan omongan warga. Hal ini membuat anak yang menikah karena hamil di luar nikah merasa minder dan tidak percaya diri untuk berhubungan dengan masyarakat, sehingga mereka sering menutup diri karena takut ditanyai soal pernikahannya.

\section{KESIMPULAN}

Berdasarkan hasil penelitian dan hasil pembahasan dapat disimpulkan bahwa:

1. Pernikahan anak di kampung Akad masih banyak terjadi. pernikahan anak di kampung Akad ini sebagian besar telah bercerai, sebahagian yang lain tidak harmonis dan ada juga yang menikah lagi, hanya ada satu keluarga yang cukup harmonis, hal karena suami yang rajin dan berasal dari keluarga yang relatif mapan.

2. Faktor penyebab pernikahan anak di Kampung Akad Kenagarian 
Padang XI Punggasan Pesisir Selatan disebabkan oleh (1) faktor pendidikan orang tua. Pendidikan orang tua yang rendah mendorong terjadinya pernikahan anak, karena kurangnya kesadaran orang tua terhadap pentingnya pendidikan, memicu terjadinya pernikhan anak. (2) faktor kemiskinan/ekonomi. Faktor kemiskinan juga mempengaruhi terjadinya pernikahan anak. faktoer kemiskinan mendorong orang tua untuk menikahkan anaknya dengan tujuan agar dapat membantu ekonomi keluarga. (3) tradisi/sosial budaya. Faktor ini menjadi salah satu penyebab masyarakat kampung Akad melakukan pernikahan anak, seperti tradisi rabab dan orgen tunggal. dan (4) pergaulan bebas. Faktor pergaulan bebas mendorong terjadinya pernikahan anak sehingga perempuan hamil diluar nikah, dan mereka harus melakukan pernikahan anak. Namun faktor yang paling menonjol adalah faktor pendidikan orang tua. Pendidikan orang tua ini berpengaruh karena dengan pendidikan orang tua yang rendah sehingga mendorong anaknya untuk putus sekolah dan akhirnya menikah di usia anak.

3. Dampak pernikahan anak di Kampung Akad Kenagarian Padang XI Punggasan Pesisir Selatan dapat dilihat dari (1) segi keluarga. Dari segi keluarga pasangan yang melakukan pernikahan anak ini sangat jarang rumah tangga mereka yang bertahan lama. Karena pasangan yang melakukan pernikahan anak ini sering bertengkar dan akhirnya
Volume 2 No. 42019

bercerai. (2) segi ekonomi. pasangan yang melakukan pernikahan anak sering bercerai karena masalah ekonomi. Penghasilan yang tidak menentu membuat rumah tangga mereka menjadi tidak harmonis, karena tidak biaya untuk hidup seharihari yang cukup besar. dan (3) segi lingkungan sosial. Pasangan yang melakukan pernikahan anak tidak mampu menjalin hubungan dengan masyarakat sekitar karena sering diejek oleh masyarakat. Dan mereka sering dipandang sebelah mata oleh masyarakat maupun teman sebayanya.

Namun dampak dari pernikahan anak di kampung Akad yang paling menonjol dapat dilihat dari aspek ekonomi. Ekonomi keluarga yang melakukan pernikahan anak dikampung Akad tidak menentu dan banyak diantaranya yang mengalami kegagalan dalam rumah tangganya dikarenakan aspek ekonomi ini.

\section{DAFTAR PUSTAKA}

Aprianti, A., Shaluhiyah, Z., Suryoputro, A., \& Indraswari, R. (2018). Fenomena Pernikahan Dini Membuat Orang Tua dan Remaja Tidak Takut Mengalami Kehamilan Tidak Diinginkan. Jurnal Promosi Kesehatan Indonesia, 13(1), 61-73.

Djamilah, D., \& Kartikawati, R. (2014). Dampak Perkawinan Anak di Indonesia. Jurnal Studi Pemuda, 3(1), 1-16.

Kartasapoetra, dan Kreimers. (1987). Sosiologi Umum. Jakarta: Bina

Reskia, S., \& Herlina, Z. (2014). Pengaruh Tingkat Pendidikan Orang Tua terhadap Prestasi 
312 | Fenomena Pernikahan..

Belajar Siswa di SDN Inpres 1 Birobuli. Jurnal Dikdas, 2(2).

Siregar, N. S. S. (2017). Persepsi Orang Tua terhadap Pentingnya Pendidikan bagi Anak. JPPUMA Jurnal Ilmu Pemerintahan dan Sosial Politik Universitas Medan Area, 1(1), 1127..

Sjafari, Agus. (2014). Kemiskinan Dan Pemberdayaan Kelompok. Yogyakarta: Graha Ilmu

Sobarsa. (2015). Mengembangkan Budaya Membangun Ekonomi Rakyat. Jakarta: Mitra Wacana Media.

Sudibyo, lies. (2013). Ilmu Sosial Budaya Dasar. Yogyakarta: CV Andi Offset

Suhaida, S., Hos, H. J., \& Upe, A. (2018). Pergaulan Bebas Di Kalangan Pelajar (Studi Kasus Di Desa Masaloka Kecamatan Kepulauan Masaloka Raya Kabupaten Bomabana). Jurnal Neo Societal, 3(2).

Suryosubroto. (2010). Beberapa aspek dasar-dasar kependidikan. Jakarta: Rineka Cipta.

Salmah, S. (2017). Pernikahan Dini Ditinjau Dari Sudut Pandang Sosial Dan Pendidikan. AlHiwar: Jurnal Ilmu dan Teknik Dakwah, 4(6).

Walgito, Bimo. (2002). Bimbingan Konseling Perkawinan. Yogyakarta: Andi.

Wulandari, S. S. (2014). Pengaruh status ekonomi keluarga terhadap motif menikah dini di perdesaan. Jurnal Sosiologi, 2(1), 53-62. 